\title{
RESULTS OF INCORPORATING THE STRATIGRAPHY WITHIN THE EVAPORITIC SEQUENCE INTO THE VELOCITY FIELD FOR RESERVOIR CHARACTERIZATION
}

\author{
Livia Falcão ${ }^{1}$, Alexandre Maul ${ }^{1}$, Fernanda Gobatto², \\ Gerardo González ${ }^{3}$ and María de Los Ángeles González ${ }^{3}$
}

\begin{abstract}
There are many ways to build velocity models for seismic migration purposes, either by using inversion algorithms, approximations by constant or variables velocities, including or not including anisotropic parameters, etc. The key aim of these alternatives is to generate a seismic image with better definition and more resolution and therefore, the possibility of obtaining better amplitude responses. However, a good velocity model must be built for further applications derived from seismic data, such as acoustic and elastic inversions, uncertainty analysis of reservoir properties, studies concerning also quality and depth positioning, geomechanical studies, pore pressure estimation regarding drilling risks, among other applications. Amplitude response, as well as other derivative seismic attributes, such as acoustic and elastic impedance, or its associated elastic parameters (coefficient of rigidity, shear modulus, etc.) are important parameters for reservoir properties distribution which allied to well data, could ensure a robust distribution of the velocity variations for each geologic unit. Consequently, it's important to take into account the uncertainties and refinements described before to obtain a reliable velocity model. In this article, we propose a methodology to build seismic velocity models for the evaporitic section considering the presence and variability among different types of salts within it, which strongly influence the reservoir response in the pre-salt section of Santos and Campos Basins. This method considers the workflows integration developed to construct velocity models for the evaporitic section, besides allowing uncertainties analysis and emphasizing where seismic amplitudes can be adequately used for reservoir characterization.
\end{abstract}

Keywords: amplitude responses, attributes, salt, pre-salt, uncertainties.

RESUMO. Atualmente existem muitas alternativas para construção de modelos de velocidades com propósitos de migração sísmica, seja usando algoritmos de inversão ou aproximações por estimativas de velocidades constantes e/ou variáveis, inserindo ou não parâmetros de anisotropia, etc. Tais alternativas têm como objetivo principal gerar uma melhor imagem sísmica (em definição e resolução) e, consequentemente, melhores respostas de amplitude para utilização na interpretação dos dados e possível geração de atributos. Entretanto, um bom modelo de velocidades deve ser construído visando diversas outras aplicações que derivam do dado sísmico, tais como inversão para estimativa de propriedades acústicas e/ou elásticas, estudos de incerteza, geomecânica, inclusive estimativas de pressão de poros para riscos de perfuração, dentre outras aplicações. A amplitude, assim como outros atributos sísmicos derivados, como impedância acústica e elástica ou parâmetros elásticos associados (coeficiente de rigidez, módulo de cisalhamento), são parâmetros importantes para a definição das propriedades de reservatório que, aliada a informação obtida dos dados de poços, possibilita a distribuição, de forma mais robusta, das variações de velocidades presentes na camada de sal. Portanto, é importante considerar as incertezas e refinamentos provenientes da mesma nas estimativas para a obtenção do modelo de velocidades. Neste artigo apresentamos um método para a construção de modelos de velocidades sísmicas considerando a presença e alternância de diferentes tipos de rochas na seção evaporítica que influenciam, fortemente, na definição e caracterização sísmica dos reservatórios da seção pré-sal das Bacias de Santos e Campos. A aplicação deste método considera a integração de fluxos de trabalho desenvolvidos para a construção de modelos de velocidade para a sequência evaporítica, além de possibilitar a estimativa de incertezas e enfatizar em que a amplitude sísmica pode ser utilizada adequadamente para a caracterização de reservatórios.

Palavras-chave: respostas de amplitude, atributos, sal, pré-sal, incertezas.

\footnotetext{
1 Petróleo Brasileiro S.A., Av. República do Chile, 330, Ed. Ventura, 9o. andar, Torre Leste, Centro, 20031-171 Rio de Janeiro, RJ, Brazil. Phone: +55(21) 2144-0922/ 2144-3069 - E-mails: liviafalcao@petrobras.com.br; alexandre.maul@petrobras.com.br

2 Petróleo Brasileiro S.A., Av. Antônio Carlos Magalhães, 1113, Pituba, 41825-903 Salvador, BA, Brazil. Phone: +55(71) 3348-4821

- E-mail: fernandaoliveira@petrobras.com.br

3 Paradigm Brazil, Av. Rio Branco, 138/1702, Centro, 20040-002 Rio de Janeiro, RJ, Brazil. Phone: +55(21) 3043-6500 - E-mails: gerardo.gonzalez@pdgm.com; maria.gonzalez@pdgm.com
} 


\section{INTRODUCTION}

Several discoveries had been announced for the pre-salt section of Santos and Campos Basins (Barra Velha and Macabu Formations), in the Brazilian Offshore. Many discussions concerning a more accurate velocity model building for seismic migration purposes (algorithms, constant or variables velocities, anisotropy) intend to allow the best seismic image generation and how to obtain better amplitude responses.

In general, reservoir characterization workflows consider amplitude response as unique due to rock impedance contrasts. However, it is known that there are several other factors related to geologic complexity, the acquisition parameters, the processing strategies, etc. (Lal et al., 2010).

Homogeneous and stratified evaporites, faulted carbonate rocks, mini-basins in post-salt section, and others, turn the velocity model building a big challenge process when as compared with other areas, like Gulf of Mexico (Zhang \& Zhang, 2008; Huang et al., 2009). Figure 1 illustrates a structural complexity example to be considered in seismic velocities studies.

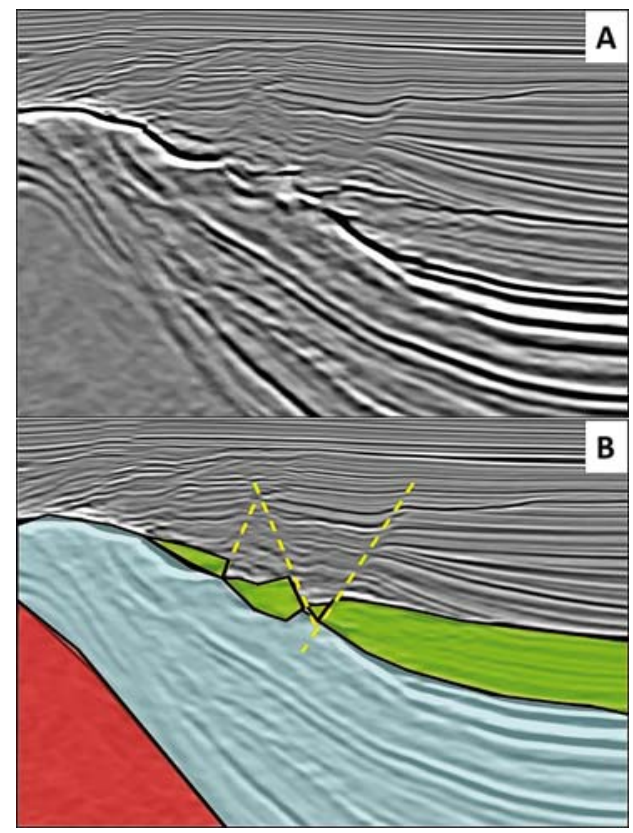

Figure 1 - Complex geologic scenario: (A) seismic section and (B) schematic interpretation. In green, the representation of post-salt carbonates; in blue, the stratified evaporitic section; and in red, the homogeneous salt, besides the mapped faults in yellow dotted lines (Jardim et al., 2015; Maul et al., 2015).

Difficulty of distinguishing which factors could cause uncertainties in seismic amplitude indicate the need to evaluate the amplitude response before use it. However, it is reasonable to consider:
1) Geologic complexity when building velocity model, in order to ensure seismic images confidence;

2) Frequency content defining resolution and what is being interpreted; and

3) Other considerations, such as signal-noise ratio, phase, etc.

The $1 \mathrm{D}$ analysis application, using all available logs and cutting samples in the salt section, was first presented by Amaral et al. (2015). This could be considered as an initial geologic approach as a trend on the 3D seismic velocity modeling, according to Falcão et al. (2014) and Maul et al. (2015). Yamamoto et al., 2016 have studied another field in Santos Basin with similar results compared to Amaral et al. (op cit.).

Using these mentioned approaches, many authors have presented ways, to include the existing stratifications within the evaporitic section, trying to better represent its heterogeneity: Maul etal. (2015, 2016), Borges et al. (2015), Jardim etal. (2015), Meneguim et al. (2015, 2016), Oliveira et al. (2015), González et al. (2016), Gobatto et al. (2016) and Yamamoto et al. (2016). These authors based their approaches on seismic attributes as amplitude, relative acoustic impedance, absolute impedance, seismic facies analysis, etc.

Therefore, the workflow presented in Figure 2 allows the generation of more reliable geological information for the salt section, including heterogeneity inside it. This kind of geological velocity modeling could be used for many purposes such as illumination studies, seismic processing, uncertainty analysis, geomechanical studies, etc.

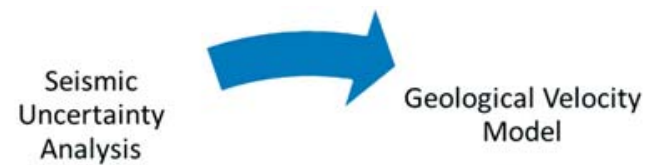

(3D)

(3D)

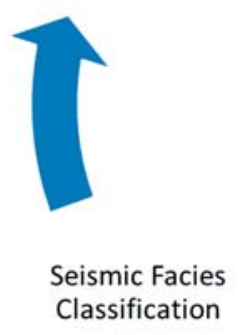

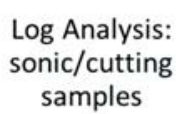

(1D)

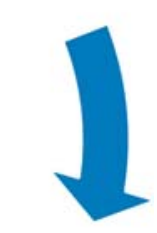

Seismic Inversion

(3D)

Figure 2 - Workflow to generate a more realistic geological seismic velocity model (Maul et al., 2016; González et al., 2016, Gobatto et al., 2016). 


\section{METHODOLOGY}

The primary motivation for applying the proposed methodology arose from well logs observation in the evaporitic section of Santos and Campos Basins. The analysis of these data indicates remarkable velocity variation due to the presence of different types of stratified salts. Therefore, we assume that the common practice of establishing a constant or almost constant interval velocity with very slight variations in the salt sequence, would mask the existent geology of the pre-salt reservoirs and could impact directly on the quality of their seismic response.

The method takes into account seismic response (interface reflectors) derived from the presence of lithologic stratification within the evaporitic section, characterized by the presence/alternance of Halite, Anhydrite, Tachydrite, Carnallite, Sylvite and other evaporites (Oliveira et al., 2015; Amaral et al., 2015; Meneguim et al., 2015, 2016; Gobatto et al., 2016), as well as possible presence of igneous rocks as described in Oliveira et al. (2015).

Halite, whose velocity is around $4500 \mathrm{~m} / \mathrm{s}$, occurs in larger (at least 80\%) proportion. Some authors as Jackson et al. (2015) and Yamamoto et al. (2016) indicated this proportion is over $80 \%$. Therefore the Halite velocity could be considered as the reference, or the background of the sequence. In contrast, Tachydrite, Carnallite and Sylvite represent lower velocities and commonly are referred as "Low Velocity Salts". Anhydrite and Gypsite correspond to "High Velocity Salts". In addition, some igneous rocks within the salt section were described as having also "High Velocity" behavior (Oliveira et al., 2015; Amaral et al., 2015).

Seismic response combined with well logs study allows the possibility to distribute geologically the velocity variation inside the evaporitic sequence. However, some wells are not logged in this section. Thus, it is helpful the use of lithologic description derived from cutting samples, as presented by Amaral et al. (2015), Silva \& Rodrigues (2016) and Yamamoto et al. (2016).

The well data analysis allows the estimation of a suitable velocity value for each identified lithotype, as well as their proportions within the evaporitic section, at each well location.

Figure $3 \mathrm{~A}$ illustrates the match between seismic amplitudes stratifications within the evaporitic section and well information (logs, lithologic descriptions). Figure 3B shows the lithologic proportion per well regarding the "salt" group: background, high velocity salts, low velocity salts.

This approach allows the evaluation of seismic event responses regarding depth positioning. It is common to observe in the evaporitic section interval velocity as close to Halite value (around $4500 \mathrm{~m} / \mathrm{s}$ ), ignoring the presence of other types of salts.
In this context, observing seismic amplitude data it is possible to identify presence of strong positive and negative amplitudes. Those are erratically distributed through evaporitic section predominantly composed by Halite. It is reasonable to assume these positive seismic reflections could be associated with Anhydrite and/or igneous rock intercalations, while negative reflections might indicate the presence of "low velocity salts" (Carnallite, Tachydrite, Sylvite, etc.). However, it is important to emphasize positive reflections may also be associated with transition between "low velocity salts" and/or Halite, as well as negative reflections may indicate the transition between "high velocity salts" to Halite.

Some aspects must be observed prior the methodology usage:

1) Seismic amplitude reflects interface only, not layers;

2) Seismic resolution criteria must be considered, since the occurrence of this rocks, anomalous in terms of velocities, are rarely larger than few tens of meters;

3) Lateral lobes from strong reflections can be inaproperly characterized as other seismic reflections if they only refer to lateral lobes in a convolution process in thin layers.

Regarding the aspects above described, and based on amplitude behavior only and geologic interpretation, it is possible to geologically extrapolate interval velocities for the entire seismic volume following only seismic amplitude response and obeying the existing lithology. Strong positive picks are assumed as "high velocity salts" (interval velocity around $6000 \mathrm{~m} / \mathrm{s}$ ), strong negative picks as "low velocity salts" (interval velocity around $4000 \mathrm{~m} / \mathrm{s}$ ) and intermediate values are defined as Halite (interval velocity $=4500 \mathrm{~m} / \mathrm{s}$ ). Figure 4 illustrates the "homogeneous" and "stratified" behaviors observed within evaporitic section.

It is worth to mention velocity values were defined from well data observations, allied to information presented by Amaral et al. (2015) (Fig. 3).

The proposed method can be adapted according to any available seismic attribute: amplitude, pseudo-impedance, relative acoustic impedance, absolute impedance, seismic facies. The results will provide velocity models that use any seismic attribute as a weight factor for modeling the evaporitic section, achieving a better representation of the lithologic heterogeneities (Maul et al., 2015; Jardim et al., 2015; Oliveira et al., 2015; Meneguim et al., 2015, 2016; González et al., 2016; Gobatto et al., 2016; Yamamoto et al., 2016). 

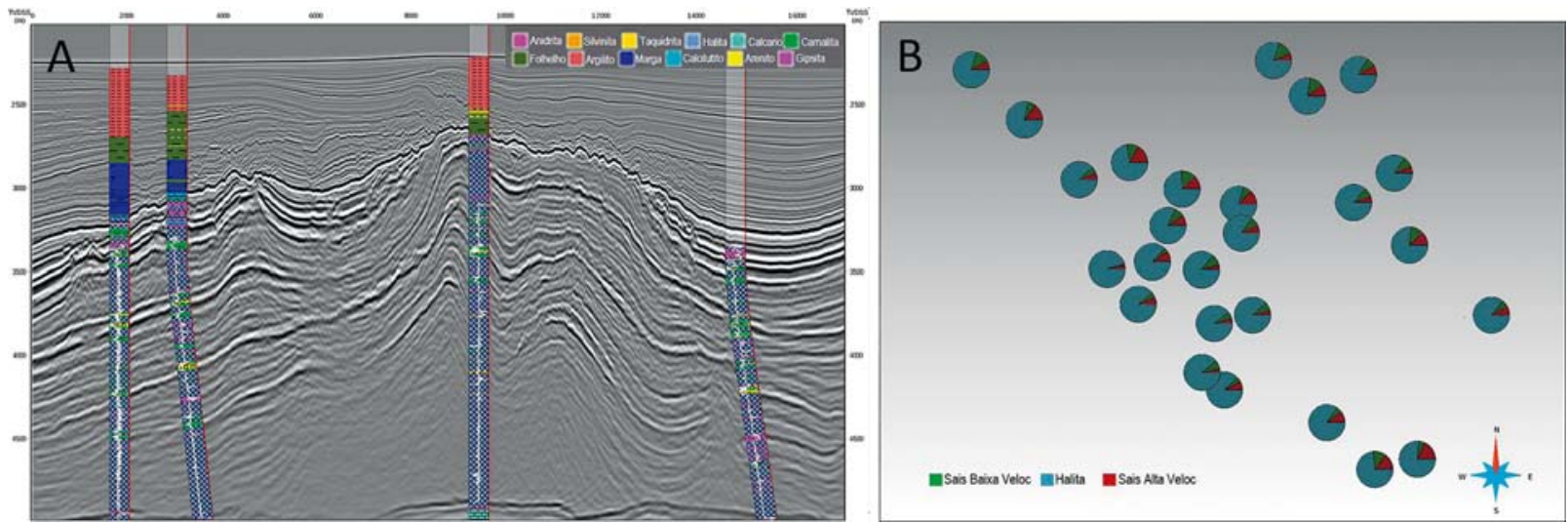

Figure 3 - (A) Arbitrary seismic line tied with few wells illustrating the observed gaps (absence of logs) for the entire salt section and the importance to use well cutting samples to complete the information. Would be possible to verify the match between "stratified" reflection in seismic and in the wells; (B) Summary report in each well location showing the salt proportion. Blue represents the Halite proportion (around 80\%), red represents the high velocity lithologies, and green represents the low velocity lithologies (adapted from Amaral et al., 2015; Maul et al., 2016; González et al., 2016; Gobatto et al., 2016; Yamamoto et al., 2016).
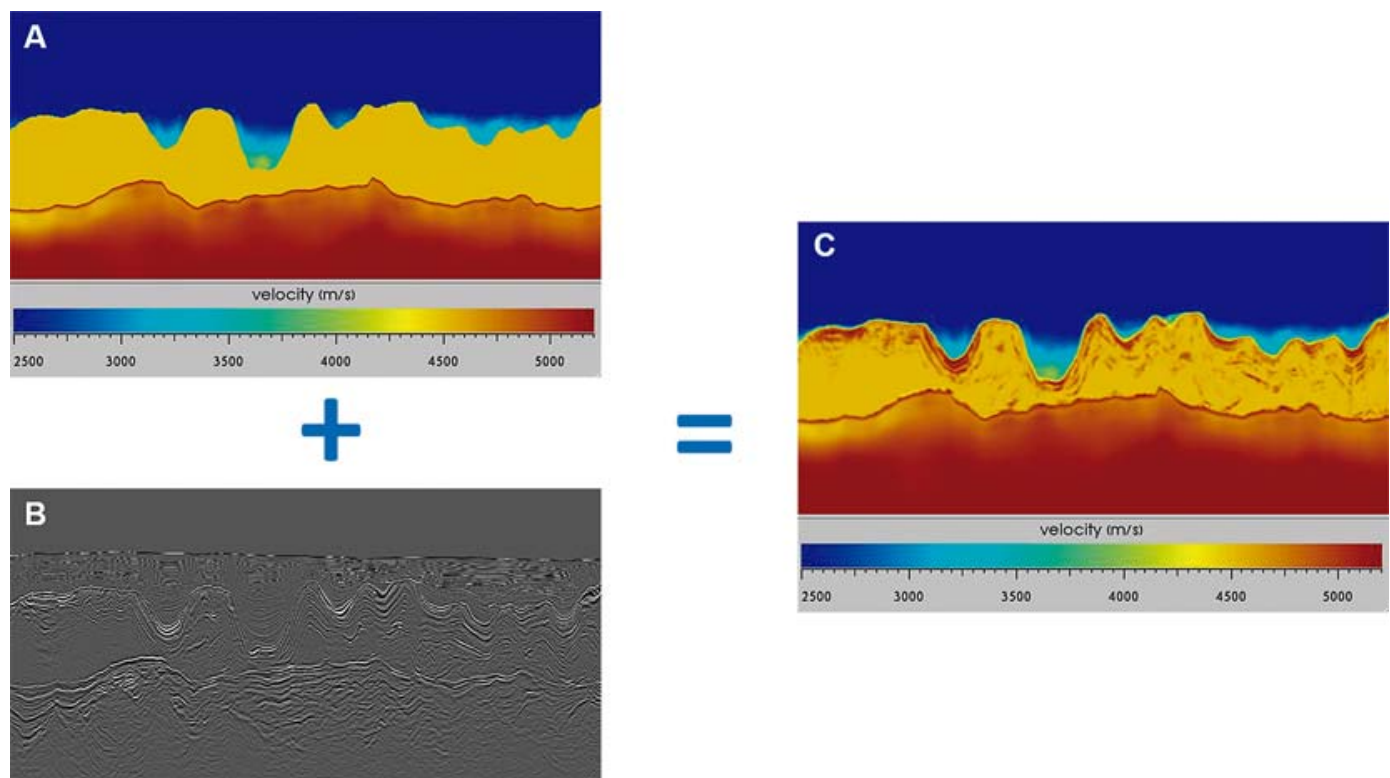

Figure 4 - Application methodology results: (A) Velocity model: almost constant values for evaporitic section; (B) Seismic amplitude cube; (C) Combination between (A) and (B) (adapted from Maul \& Falcão, 2014 in Oliveira et al., 2015).

\section{RESULTS}

The application of the proposed methodolgy have provided refined tools to establish uncertainties scenarios for depth positioning and reservoir seismic response analysis. Resultant velocity models are also more accurate inputs for illumination studies, seismic inversion, seismic migration, geomechanical analyses, etc. Several case studies derived from this methodology have been presented since 2015 .

As described in Maul et al. (2015), Jardim et al. (2015), Maul et al. (2016), González et al. (2016), Gobatto et al. (2016), this methodology enables seismic amplitude response uncertainties analyses through illumination studies to better understand the impact of velocity variations in illumination maps (hit-maps).

In Maul et al. (2015) and Jardim et al. (2015), four velocity models were built from different ways within salt section, in order to accomplish illumination studies:

1) Interval velocity resulting from seismic tomography on pre-stack migration processing (Fig. 5A);

2) Constant velocity within evaporitic section (Fig. 5B); 

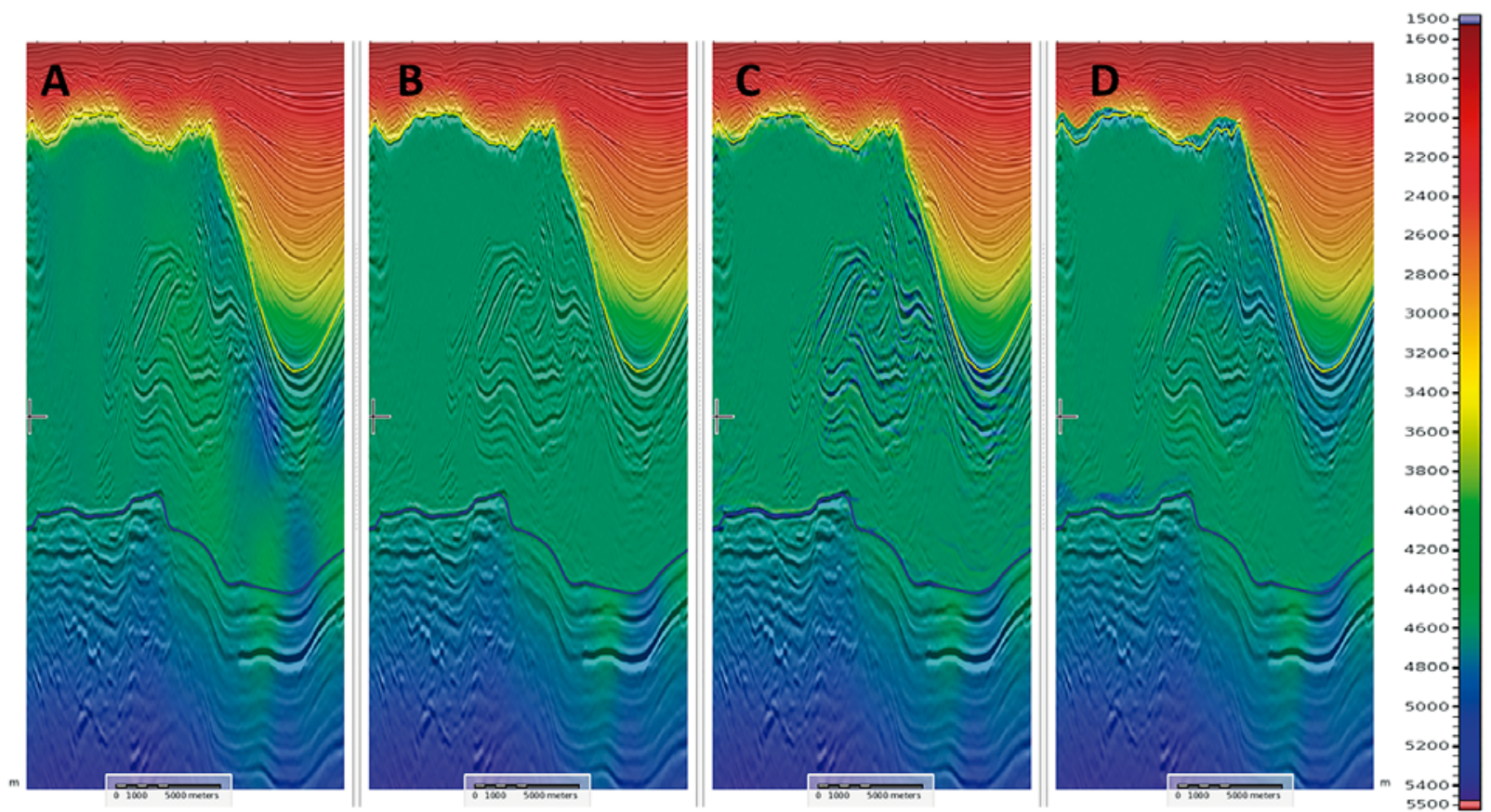

Figure 5 - Four velocity models were considered: (A) Original velocity model considering tomography for evaporitic section; (B) Constant velocity for evaporitic section (4500 m/s); (C) Geoestatistical approximation from well information and seismic facies for evaporitic section; and (D) Using seismic amplitude as a weight factor to calculate the interval velocity for evaporitic section (Maul et al., 2015; Jardim et al., 2015).

3) Velocity derived from a seismic facies study using a geostatistical approximation extrapolating obtained velocity from well logs (Fig. 5C); and

4) Velocity model using seismic amplitude as a weight factor to model the evaporitic complex, in order to achieve better heterogeneities representation (Fig. 5D).

An amplitude map were extracted from salt base (Fig. 6) in order to better understand the velocity influence over seismic migrated data reservoir response. Additionally, four hit-maps obtained through illumination studies using each generated models were generated (Figs. 6B, 6C, 6D and 6E). The aim is to analyse how illumination varies according to the velocity model used. In areas where there are not large variations among the maps, we consider the amplitude values are not strongly dependent of the velocity model. As a consequence, the amplitude response may be used more confidentially for the property reservoir extrapolation.

In another approach, Oliveira et al. (2015) found higher values of the average interval velocities map for the evaporitic section for smaller thicknesses and from the same section (Fig. 7). This behavior backs the inference there is higher stratified Anhydrite concentration on portions of lower salt section thicknesses due to the Halite escape caused by the overloading of Albian carbonates, positioned within mini-basins above the salt section. These authors advocate the nonequivalent behavior at the Southeast portion of the maps is explained by presence of thick Albian carbonates layer above salt section superposed by volcanic rocks. These post-salt sequences together act attenuating signal energy and consequently, filtering stratifications within the evaporitic section. Therefore, it can be understood as problem related to acquisition or at least to processing strategies.

According to obtained results, integration of three important studies of reservoir seismic characterization (seismic inversion, facies classification and uncertainty analysis) seems to be the key to better accomplish for the entire methodology. This is well presented in Meneguim et al. (2015), Maul et al. (2016), González et al. (2016), Meneguim et al. (2016), Gobatto et al. (2016) and Yamamoto et al. (2016). These authors suggest an improvement of the method by including a facies classification analysis using impedance response, through probabilistic approach and taking into account the variation of velocity values for each type of salt (Fig. 8).

Besides obtaining a better positioning for the salt layers than using any seismic attributes, this probabilistic approach allows the application of different cut-offs to generate several scenarios for the occurrence of thin layers that cannot be characterized because of the vertical resolution limitation of the seismic data. 


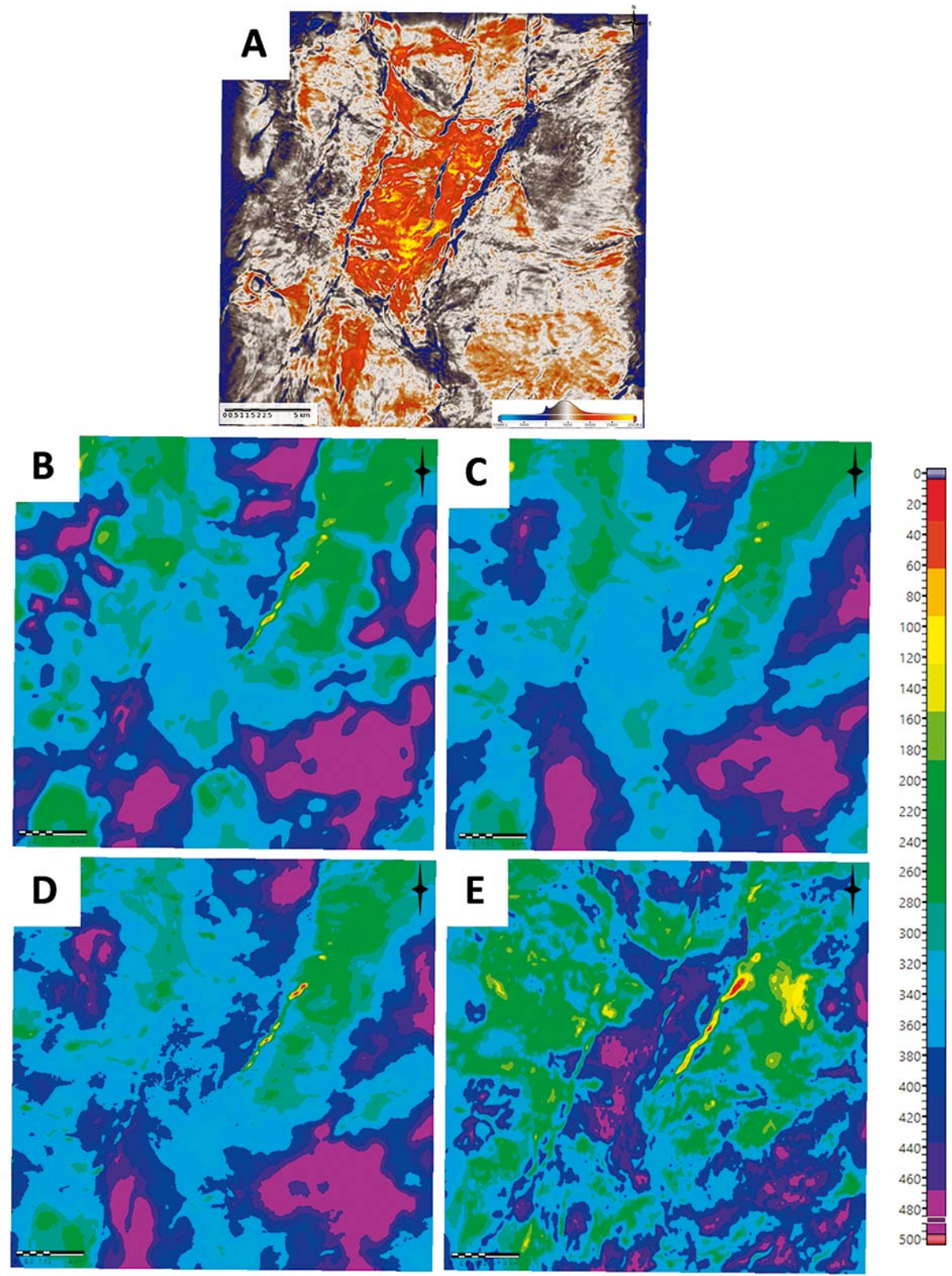

Figure 6 - (A) Base of salt seismic amplitude map, top of reservoir equivalent. There is a NE-SW trend related to faults and/or carbonate accumulations. Orange amplitudes enclose reservoir; (B) Obtained hit-map (ray tracing considering original velocity model from seismic tomography as input for the evaporitic section); (C) Obtained hit-map (ray tracing considering constant velocity within salt section); (D) Obtained hit-map (ray tracing considering velocity model built from combination between seismic facies study and geostatistical approximation); and (E) Obtained hit-map (ray tracing considering velocity model conditioning by amplitude response for salt section). Cold colors represent high rays' concentration. Adapted from Maul et al. (2015), Jardim et al. (2015).

Knowing the stratified salt position and velocity variation from wells, makes possible to perform a sensitivity analysis for depth forecast in new wells to be drilled, as mentioned in Meneguim et al. $(2015,2016)$.

Regarding depth migration Gobatto et al. (2016) have presented better gather alignment using stratification salts only, with few effort of tomography for the salt section (Fig. 9).

\section{CONCLUSIONS}

According to the demonstrated results, interval velocity model built for salt section have a strong influence for amplitude response to be mapped and interpreted below this section, the pre-salt reservoir section. Therefore, the observed geology must be represented as much as possible including the observed 

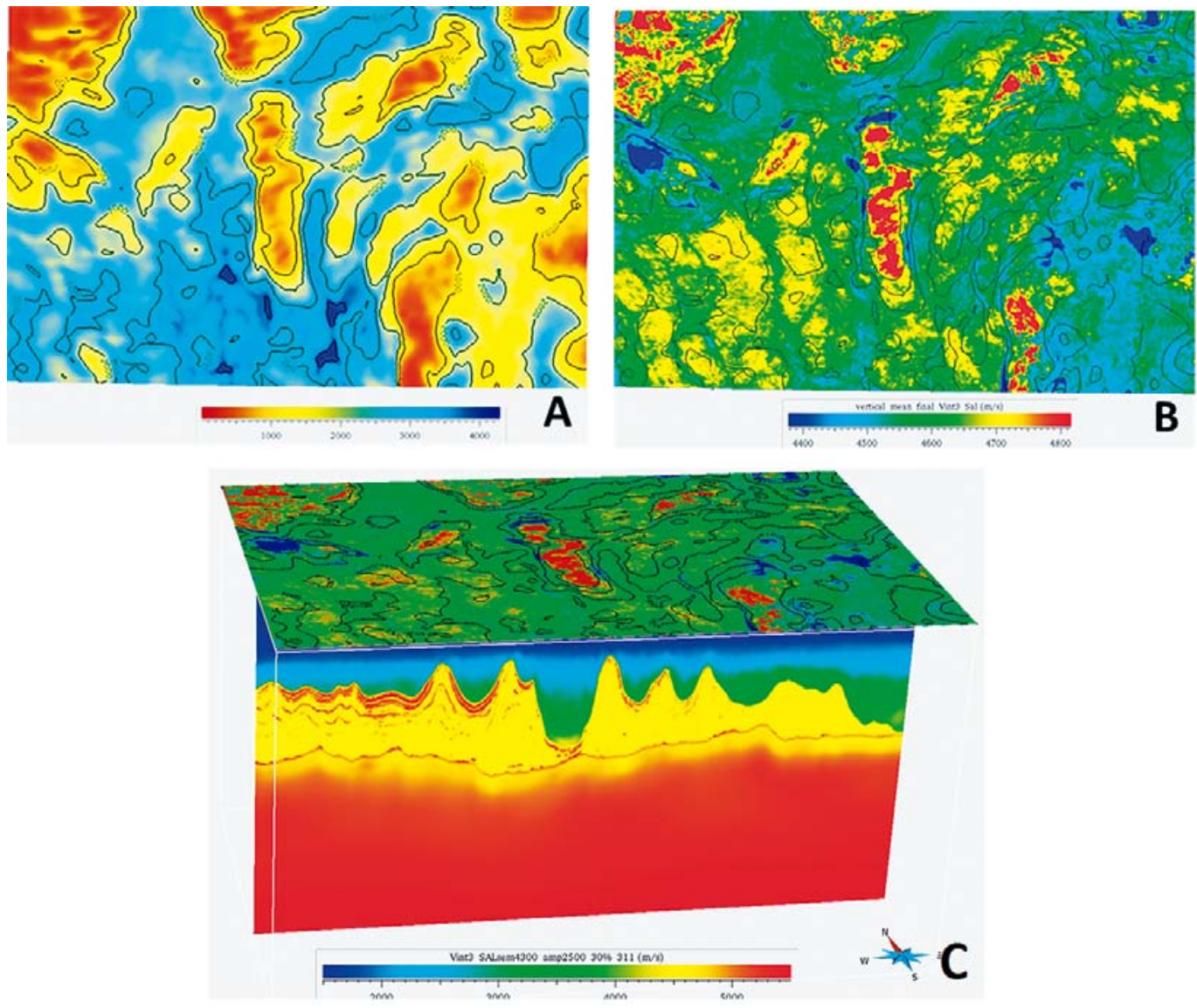

Figure 7 - (A) Salt section thickness map. (B) Interval mean velocity map of evaporitic section - contour lines represent thickness map level curves. Observe the existing coincidence between high velocity values and low thickness values. (C) Map "B" over 3D velocity section to illustrate existing behavior in all generated model. Adapted from Oliveira et al. (2015).

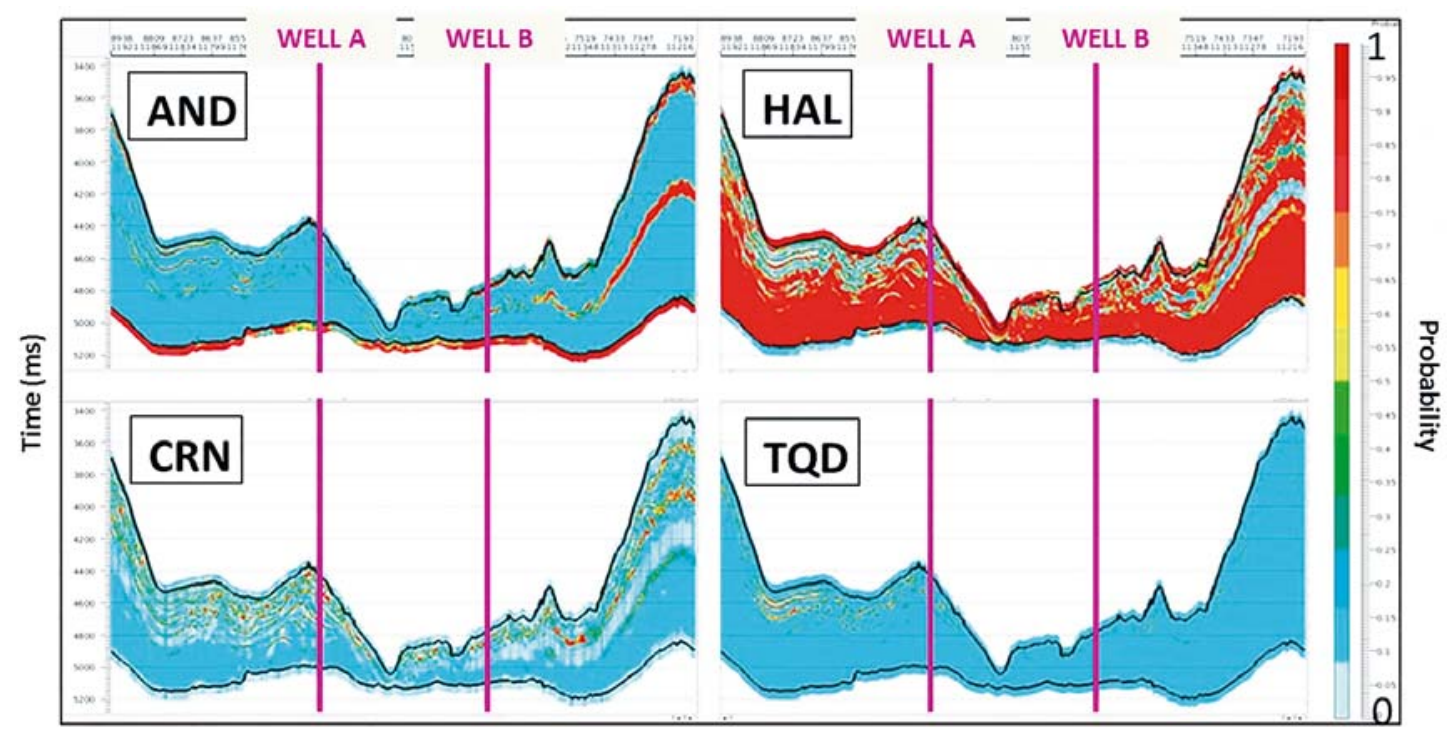

Figure 8 - Arbitrary section showing most probable facies, for each evaporite class. Red indicates the most probable occurrence. AND means Anhydrite, HAL is Halite, CRN represents Carnallite and TQD corresponds to Tachydrite (Meneguim et al., 2015, 2016; Maul et al., 2016; González et al., 2016; Gobatto et al., 2016). 


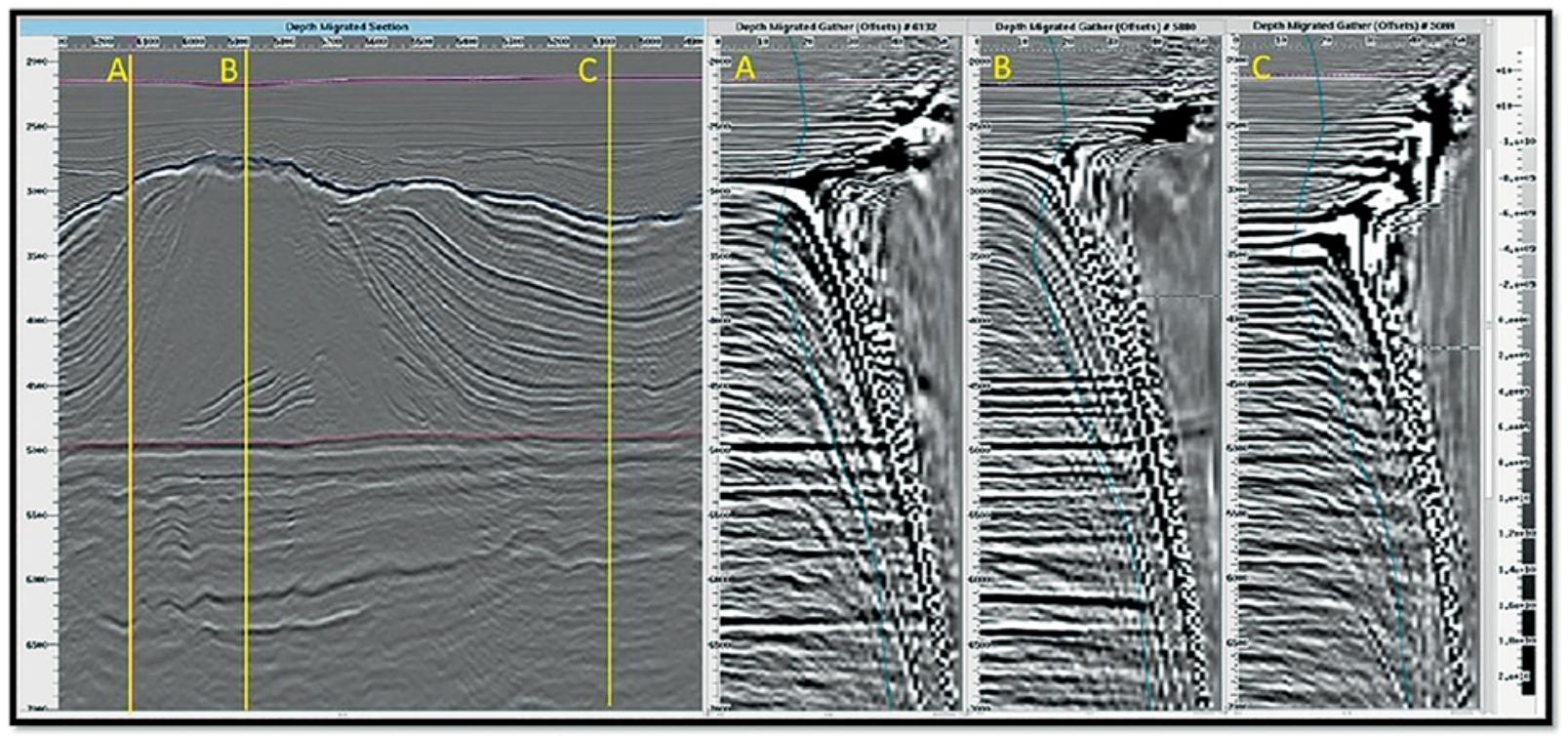

Figure 9 - Gather panels showing the move-out effect when using the stratified salt within the evaporitic section, for different "salt domains" like homogeneous, stratified, miscellaneous (Gobatto et al., 2016).

stratifications within this evaporitic sequence. As expected, building a more accurate interval velocity model seems to be the key concept to achieve a representative response in seismic images.

Heterogeneities inside evaporitic section could better be represented when simplistic models are not being used as, for instance, by considering a constant or approximately constant velocity in this section. Other approaches as the models presented by Maul et al. (2015) and Jardim et al. (2015), created using geostatistical extrapolation of well data, would represent a reliable stratification scenario, but without the guarantee of matching the structures positioning. However, models based on the application of an amplitude weight factor (Maul et al., 2016; González et al., 2016; Gobatto et al., 2016) honoring the stratifications positioning caused by contrasts between different salt layers and other rocks turn it more promising.

The methodology adaptation using pseudo-impedance, relative acoustic impedance, absolute impedance and seismic facies studies have shown even more accurate and robust results, both in terms of resolution and reliable velocity values.

Furthermore, uncertainties analyses is a useful tool to evaluate the confidence degree of amplitude response for reservoir once it takes into account several important considerations for seismic image generation.

Providing more geological contrasts when building velocity models by the proposed methodology seems to be an useful way to establish boundary condition to guide seismic tomography, seeking for the best seismic image.
According to Guo \& Fagin (2002), seismic tomography itself may not be a perfect solution. Therefore geological knowledge of the study area and well information are required for the entire velocity modeling workflow. In this work we demonstrated it.

Thus, the model resulting from the application of this methodology can be considered as a priori model for seismic depth migrations, in order to obtain better images and more confidence on amplitude usage for reservoir characterization workflows.

\section{ACKNOWLEDGEMENTS}

The authors would like to thank Petrobras and Paradigm for giving the support, time and data for this research, as well as for allowing the publication.

\section{REFERENCES}

AMARAL PJT, MAUL AR, FALCÃO L, CRUZ NMSM, GONZÁLEZ MA \& GONZÁLEZ G. 2015. Estudo estatístico da velocidade dos sais na camada evaporítica na Bacia de Santos. In: 14th International Congress of the Brazilian Geophysical Society - Rio de Janeiro, RJ, Brazil. Extended Abstracts, 666-669, http://dx.doi.org/10.1190/sbgf2015-131.

BORGES F, APOLUCENO D, SELBACH H, MAUL A \& LIMA G. 2015. Thickness-based approach for evaporites seismic velocities in Campos Basin. In: 14th International Congress of the Brazilian Geophysical Society - Rio de Janeiro, RJ, Brazil. Extended Abstracts, 808-810, http://dx.doi.org/10.1190/sbgf2015-158. 
FALCÃO L, MAUL A, NOVELLINO V \& GONZÁLEZ G. 2014. Construção de Modelos Geológicos de Velocidades. Aplicações em: Estudos de Iluminação, Reprocessamento e Geração de Cenários Geofísicos de Reservatórios. In: XIV SIMGEF (Simpósio de Geofísica de Petrobras). Vitória - ES, Brazil. Petrobras - Internal Publication.

GOBATTO F, MAUL A, FALCÃO L, TEIXEIRA L, BOECHAT JB, GONZÁLEZ M \& GONZÁLEZ G. 2016. Refining Velocity Model within the Salt Section in Santos Basin: an Innovative Workflow to include the Existing Stratification and its Considerations. SEG, Society of Exploration Geophysicist - Dallas, TX, USA. Extended Abstracts, 5328-5333, http://dx.doi.org/10.1190/segam2016-13685489.1.

GONZÁLEZ M, GOBATTO F, MAUL A, FALCÃO L, GONZÁLEZ G, OLIVEIRA L, MENEGUIM T \& AMARAL PJ. 2016. Proposed workflow to incorporate stratification within salt section using velocity and seismic attributes. In: 3rd EAGE/SBGf Workshop - Rio de Janeiro, RJ, Brazil. Extended Abstracts, http://dx.doi.org/10.3997/2214-4609.201600050.

GUO N \& FAGIN S. 2002. Becoming Effective Velocity-Model Builders and Depth Imagers, Part 2 - The Basics of Velocity-Model Building, Examples and Discussions. The Leading Edge, 21(12): 1210-1216.

HUANG Y, ZHANG Y \& ZHANG H. 2009. The Benefit of TTI Reverse Time Migration for Subsalt Imaging, Gulf of Mexico. In: 71th EAGE Conference \& Exhibition - Amsterdam, Netherlands. D0I: 10.3997/22144609.201400392.

JACKSON CAL, JACKSON MPA, HUDEC MR \& RODRIGUEZ CR. 2015. Enigmatic Structures within Salt Walls of the Santos Basin - Part 1: Geometry and Kinematics from 3D Seismic Reflection and Well Data. Journal of Structural Geology, 75: 135-162.

JARDIM F, MAUL A, FALCÃO L \& GONZÁLEZ G. 2015. Estimating amplitude uncertainties through illumination studies for a presalt reservoir. In: 14th International Congress of the Brazilian Geophysical Society - Rio de Janeiro, RJ, Brazil. Extended Abstracts, http://dx.doi.org/10.1190/sbgf2015-160.

LAL H, BISWAL SK \& NANGIAJL. 2010. Pittalls in seismic amplitude interpretation: Lessons from Oligocene channel sandstones. The Leading Edge, 29: 384-390.

MAUL AR, JARDIM F, FALCÃO L \& GONZÁLEZ G. 2015. Observing amplitude uncertainties for a pre-salt reservoirs using illumination study
(Hit-Maps). In: 77th International Conference and Exhibition, EAGE Madrid, Spain. Extended Abstracts, http://dx.doi.org/10.3997/22144609.201412921.

MAUL A, FALCÃOL, GOBATTOF, NOVELLINO V, JARDIM F, OLIVEIRAL, MENEGUIM T, AMARAL PJ, BORGES F, TEIXEIRA L, MONTEIRO RC, GONZÁLEZ G \& GONZÁLEZ M. 2016. Incorporação de Estratificações dentro da Seção Evaporítica utilizando Velocidadese Atributos Sísmicos. IGP-152 Informe Geofísico da Petrobras - Internal Publication.

MENEGUIM TB, MENDES SC, MAUL AR, FERNANDES LF, FARIAS MG \& GONZÁLEZ G. 2015. Combining seismic facies analysis and well information to guide new interval velocity models for a pre-salt study, Santos Basin, Brazil. In: 14th International Congress of the Brazilian Geophysical Society \& EXPOGEF - Rio de Janeiro, RJ, Brazil. Extended Abstracts, 1365-1368, http://dx.doi.org/10.1190/sbgf2015-271.

MENEGUIM T, MENDES SC, MAUL A, FALCÃO L, GONZÁLEZ M \& GONZÁLEZ G. 2016. Refinamento do Modelo de Reservatórios a partir da Caracterização das Estratificações Saliferas baseada em Atributos Sísmicos, Pólo Pré-Sal da Bacia de Santos. In: 48º Congresso Brasileiro de Geologia - Porto Alegre, RS, Brazil. CD-ROM.

OLIVEIRA L, FALCÃO L, MAUL A, ROSSETO J, GONZÁLEZ M \& GONZÁLEZ G. 2015. Geological velocity approach in order to obtain a detailed velocity model for the evaporitic section, Santos Basin. In: 14th International Congress of the Brazilian Geophysical Society \& EXPOGEF - Rio de Janeiro, RJ, Brazil. Extended Abstracts, 1374-1377, http://dx.doi.org/10.1190/sbgf2015-273.

SILVA DB \& RODRIGUES LHO. 2016. Critérios para Interpretação da Coluna Geológica da Fm. Ariri - Sequência Evaporítica da Bacia de Santos. In: STOG - Seminário Técnico de Operações Geológicas da Petrobras. Rio de Janeiro - RJ. Petrobras - Internal Publication.

YAMAMOTO T, MAUL A, BORN E, GOBATTO F, CAMPOS MT \& GONZÁLEZ M. 2016. Incorporação de Estratificações Salifferas através do Modelo de Velocidade em um Projeto da Bacia de Santos. In: VII Simpósio Brasileiro de Geofísica - Ouro Preto, MG, Brazil. CD-ROM.

ZHANG HJ \& ZHANG Y. 2008. Reverse time migration in 3D heterogeneous TTI Media. In: 78th Annual International Meeting, SEG - Las Vegas, Nevada, USA. Expanded Abstracts, 2196-2200. 